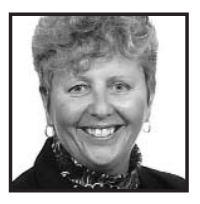

\title{
Multi-Modal Responses to Literature: A Teacher Educator's Classroom Inquiry
}

\author{
Susan E. Elliott-Johns, Nipissing University
}

\section{ABSTRACT}

Approaches to the effective integration of technology in learning and teaching continue to develop at lightning speed. This ongoing inquiry explores multi-modal literature response as a relevant component of teacher education. Illustrative examples of four multi-modal literature responses created by teacher candidates are embedded as hyperlinks. The author's work highlights multi-modal expression as an innovative approach to literature response in contemporary classrooms; one way of "bridging" print and digital literacies; and as professional learning for both pre-service and practicing teachers in the "new literacies."

For the reader, the literary work is a particular and personal event: the electric current of his mind and personality lighting up the patterns of symbols on the printed page. Or perhaps we should say that the symbols take meaning from the intellectual and emotional context the reader provides. (Rosenblatt, 2005, p. 63)

\section{Introduction}

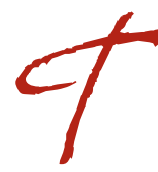

he essentials of response theory have become well known (Rosenblatt, $1978,1994,2005)$ and, over time, have contributed to changes in the way we ask students to respond to their reading in school. A central focus of Rosenblatt's reader response theory was that the readers' active participation in any reading event was equally as important as the text itself, and her work has direct relevance to the topic of multi-modal response:"While many theories of literature have 
come and gone, Rosenblatt's has endured even in the presence of emerging forms of text associated with technology" (Smith, 2008).

Literature response strategies offer ways to enable students to express their understanding and interpretations of different texts (both print and digital) in a multitude of ways, and enable teachers to assess students' demonstrations of learning and understanding. Kress and Van Leeuwen, (2001) define multimodality as, "the use of several semiotic modes in the design of a semiotic product or event, together with the particular way in which these modes are combined" (p. 20).

The approach to extending literature response strategies described and discussed in this paper involves the "multi-modal" communication of meaning constructed in response to a self-selected piece of literature. Using a wide range of multimedia, teacher candidates represented their understandings of, and connections to, themes/"big ideas" and personal interpretations of the text and expressed their responses through images, movement, text, music, and film.

Multi-modal information sources and opportunities for the construction of meaning "multi-modally" are increasingly available to students in contemporary classrooms but do require the acquisition of "new" literacies for the $21^{\text {st }}$ century by both students and their teachers.

\section{Context and Background of the Inquiry}

Prior to taking up my current position as a professor of literacy teacher education in 2006, I was a middle years teacher and school principal (K-8) for almost twenty years. My experiences as a teacher of adolescents continue to influence my inquiries into effective literacy teaching practices and, specifically, ways in which to diversify instructional repertoires of teacher candidates. The work described reports a practitioner inquiry into a teaching assignment conducted alongside teacher candidates at Nipissing University, the small university in the "Near North" of Ontario where I currently teach. The context was the one-year Consecutive B.Ed program that presently offers 60 hours of Language Arts coursework throughout the year for individuals preparing to teach at the Junior Intermediate $(\mathrm{J} / \mathrm{I})$ grade levels (Grades 4-10 in Ontario). The philosophy at the heart of the education program in the Schulich School of Education at Nipissing contends that education graduates must be computer literate in order to be competent, professional teachers today and in the future. 
This philosophy is actualized through the iTeach Laptop Learning Program for teacher candidates, and faculty strive to consistently demonstrate effective integration of educational technology for teaching and learning. Therefore, "Creating a cando culture" has become a mainstay of both the Consecutive and Concurrent education programs.

An initial catalyst for my inquiry was the design of an assignment that required a multi-modal literature response to be completed by all $\mathrm{J} / \mathrm{I}$ teacher candidates in my language arts and literacy courses. This assignment sought a) to broaden their conceptualization of "literature response" (as potential teachers of language arts), and b) to actively promote the integration of effective uses of educational technology for teaching and learning into a major assignment completed as part of the course. On completion of the assignment and after final grading, teacher candidates were invited to participate further by allowing samples of their work to be included in written papers on the topic. All teacher candidates who voluntarily agreed to contribute signed an informed consent.

Many teachers and students utilize reader response journals and learning logs (Atwell, 1990; Kooy \& Wells, 1996; Parsons, 1990), talk, write, and draw about making text-to-text-, text-to-self-and text-to-world connections (Freebody \& Luke, 2003), and some teachers and their students are also beginning to explore a broader range of responses and the construction of personal meaning through multi-modal responses. My intent in conducting an inquiry around the assignment described was to further explore the potential for "bridging" print and digital literacies in the experiential learning of my teacher candidates. Subsequently, this also enabled further examination of a specific aspect of integrating technology into their developing pedagogy for language arts teaching. In light of the need, as I see it, to increasingly (and meaningfully) "bridge" print and digital literacies in contemporary classrooms, I perceived the teacher candidates' participation in this assignment as also having an impact on broader audiences-i.e., the students they would eventually teach in $\mathrm{J} / \mathrm{I}$ classrooms. As Anstey and Bull (2006) remind us:

The world continues to change in technological, social, and economic ways. As a result, the texts we use continue to change, the ways we use literacy will change as purposes and contexts change, and literacy knowledge, skills and processes will continue to change.... Therefore, the ways we teach and learn literacy will need to change. (p. 1) 
Kress and van Leeuwen's (2001), exploration and discussion of some common principles behind multi-modal communication helped to explain the shift that has taken place (in Western society, at least), from a seeming preference for "monomodality" to crossing boundaries inspired by twentieth century semiotics, thus resulting in increased expressions of meaning across a variety of semiotic modes. Kress and van Leeuwen described "production" as "the communicative use of media, of material resources" (p. 66) and emphasized that interpretation of "production" "is never a matter of passive reception" (p.67). In the context of this inquiry and the completion of the multi-modal assignment, it was helpful to integrate Kress and van Leeuwen's work with teacher candidates' increased understandings of processes related to the construction and articulation of meaning and interpretative responses to literature.

While writing still frequently appears as the expected and dominant mode for completion of responses in J/I classrooms, Kress and van Leeuwen (1996) present a convincing case for including, "The semiotic landscape: language and visual communication" (p. 16) and for multiple modes to be as much a part of student's in-school experiences as they are in their literacy lives beyond the school:

Outside school, however, images play an ever-increasing role, and not just in texts for children. Whether in the print or electronic media, whether in newspapers, magazines, CD-ROMS or websites, whether as public relations materials, advertisements or as informational materials of all kinds, most texts now involve a complex interplay of written text, images, and other graphic or sound elements, designed as coherent (often at the first level visual rather than verbal) entities by means of layout. But the skill of producing multimodal texts of this kind, however central its role in contemporary society, is not taught in schools... We want to treat forms of communication employing images as seriously as linguistic forms have been. (Kress \& van Leeuwen, 1996, pp. 16-17)

In this paper, descriptions of the multi-modal literature responses completed by teacher candidates in classes last year (2009-2010) are illustrated by examples of work and enhanced with selected comments in teacher candidates' own "voices." Collectively, work completed for this assignment clearly demonstrated growth over time in terms of their knowledge of literature and various approaches to literature response for $\mathrm{J} / \mathrm{I}$ classrooms, thus highlighting observed benefits of being asked to construct and share multi-modal texts as part of their teacher education experience. 


\section{Purpose and Process of the Multi-Modal Assignment}

\section{Building a Repertoire of Teaching/Learning Strategies}

Teachers at all grade levels need to acquire and employ an extensive repertoire of literacy teaching and learning strategies for use in language arts classes and across other areas of the curriculum. I believe, therefore, an essential aspect of preparing individuals to teach at $\mathrm{J} / \mathrm{l}$ levels is to assist them in building confidence, and "knowledge in practice" as a result of direct experience with research-based skills, strategies, and carefully selected resources relevant to contemporary and future classrooms.

\section{Building Knowledge of Literature Selections for J/I Teaching/Learning}

Teacher candidates were asked to first identify a literature selection suitable for use in either Junior (Grades 4-6) or Intermediate (Grades 7-10) classrooms. They were also given the opportunity to select a curriculum area of their choice-for example, history or physical education-in order to underscore the importance of seeing cross-curricular connections when planning for language arts. The positive response to the assignment was palpable, and I observed a great deal of interest and enthusiasm for the assignment as soon as details were shared in class. Many began combing through different novels, picture books, non-fiction selections, and a range of other "literature," broadly defined, including poetry, song lyrics, newspaper articles, graphic texts and other electronic sources in search of a selection. They each considered a number of different genres, titles, and purposes for making their final choiceas opposed to gravitating to the first selection that came to hand (which, unfortunately, had often been my experience previously when assigning work related to literature response that called for written responses only). Teacher candidates frequently discussed with me and with each other the wide range of potential selections they were discovering, bringing various selections in to class that they were considering, and overtly expressing excitement about the opportunity to generate a multi-modal response. These discussions continued before, during, and after completion of the multi-modal responses, and I do think asking the teacher candidates to read/sample, think about, and discuss a wide range of literature selections relevant to teaching and learning in $\mathrm{J} / \mathrm{l}$ grades (i.e., to actively build on their knowledge and experience) was undoubtedly accomplished. Three comments shared by participants in the course further illustrate the sense of their increased abilities to "think like a teacher" about selecting appropriate literature for teaching and learning in their $\mathrm{J} / \mathrm{I}$ classrooms: 
Knowing more about a wide range of texts I can present to my $\mathrm{J} / \mathrm{I}$ students is beneficial to me as a teacher and, I believe, will only have positive impacts on student learning...

Incorporating technology into language arts is going to be very important for me as a teacher-and very important for the next generation of learners in my classrooms. But I also want to continue learning much more about "what's out there" for them in terms of literature to actually read and respond to...

As a teacher candidate, it is one thing that my ideology and knowledge has grown where $\mathrm{J} / \mathrm{I}$ Language Arts is concerned. But I have also seen enormous growth in my knowledge of literature and related strategies to take into my developing classroom practice...

\section{The Creation of a Multi-Modal Response}

After briefly discussing the assignment when the course outline was distributed at the beginning of the year (September), additional details were discussed further as the time approached to prepare and submit the multi-modal responses (February). The central task was first to identify an appropriate selection of literature, and then to create a response, as follows:

Identify a literature selection suitable for use in either a Junior or Intermediate curriculum area of your choice. Using your MAC computer, you are to construct a computer generated multi-modal response to your literature selection. For example, your selection might be a picture book, a novel, or even a non-fiction selection. The selection identified will provide the focus for your development of this multi-modal response. Using multimedia of your own choice, plan a literature-based response that represents your understandings and the connections made to "big ideas"/themes/ interpretations presented in the text. Your response may involve text, images, movement, music and/or any other modes you find relevant to effectively communicating your response....

(Excerpt from Course Outline EDUC 4214: Assignment \# 3, 2009-2010 - SEJ)

Individuals with specific questions/concerns/ideas readily took time to come and chat with me before or after classes, and/or came to see me during office hours. Again, I found the sheer amount of interest and engagement in this particular 
assignment unprecedented. I consistently emphasized that the result of their work was not intended to be their version of a response that a Grade 4 or a Grade 7 student in their classes might create. Rather, it was to reflect their personal response as an adult learner. That said, they were also assured the final product might well be something that they might use as an exemplar in future classes when assigning similar work to their school-age students.

\section{Submission of a Written Rationale}

The written component of the assignment required the composition of a short written paper, giving the reasons for their choice of selected literature and demonstrating their developing understanding of the purposes/uses of quality literature for instruction and learning in J/I classrooms. The "rationale" was to reflect a broad definition of literacy, as shared throughout the year in interactive class activities, discussions and assigned readings. Using examples from the literature selection chosen to support points made in the rationale was both suggested and encouraged. This written paper was to be prepared electronically and handed in on the same USB key/DVD as the multi-modal response.

\section{Outcomes}

First and foremost, despite some last-minute challenges of a technological nature, all teacher candidates had a completed multi-modal response ready to hand in on/before the due date, and the overall quality and attention to detail was impressive. Of particular interest was the significant teacher learning that became evident: not one of the 120 individuals in my three classes appeared to complete their piece of work, "just to hand in an assignment." This, in itself, went a long way to convincing me that the exercise represented an authentic, relevant, and enjoyable assignment to be completed as part of the course.

As the instructor, thoughtful planning about the submission process was vital. Submission processes were also negotiated with all teacher candidates prior to the due date. For example, some elected to hand in a USB key or DVD with a compilation of two or three different responses and it was agreed that this was fine as long as the electronic files were all clearly marked and organized. Carefully thinking 
through logistics of this phase of the assignment was essential in terms of the management, assessment, and safe return of 100+ USB keys and DVDs. The USB keys were all placed in a sealed envelope and clearly labeled when submitted for return to their owner after final placement, six weeks later. DVDs had to be submitted in a protective case and were also clearly labeled with the owner's name and section. Furthermore, the due date for this assignment was purposely planned to fall prior to the final school placement (in February-March), thus giving me ample time to review all of the work completed. The multi-modal responses averaged 5-7 minutes each in terms of viewing time, but completed responses varied in length from 2 to 35 minutes. This was the final assignment in the course; and some were able to utilize their work when out in a classroom on final practicum. Class time was also allocated for sharing and discussing their work with colleagues when they returned in April to share and discuss completed responses with colleagues in small groups. At this time I gathered additional samples of feedback from individuals in the course about the learning they felt had taken place as a result of their experience with this assignment:

The multi-modal response was truly the most unique (assignment) since it took so many various ways of responding to literature and put them all together in one presentation. This is definitely something I see using in future classroom applications since it asks students to do more than simply "write" a response. The biggest influence on me was realizing that so many different learning styles would benefit from this approach to responding to literature. So many factors went into my response to "The Giver"-text, music, images, and video, all presented on a PowerPoint -it's really inclusive, and caters to all learning styles.

\section{First and foremost, the multi-modal response screams "cross-curricular"!}

Four links to actual examples of the pre-service teachers' work will be shared and briefly discussed. Excerpts from the written rationale papers submitted have also been included in order to provide further context and background in the pre-service teachers' own voices. The illustrative links provide examples of the kinds of multimodal literature responses created. Unfortunately, the soundtracks embedded in all four of the multi-modal examples had to be removed from the links, as publishing them here would constitute copyright infringement. A fifth example could not be shared as a link as it also contained a copyrighted image. Instead, a brief description of the multi-modal response to $A$ Rose is a rose was retained and presented in the students' own voices. 
All five examples clearly illustrate the wide range of multi-modal literature responses that were created in response to five very different text selections, as follows: The North Star (an inspirational picture book by Peter Reynolds); Three Wishes: Palestinian and Israeli Children Speak (an anthology of children's voices by Deborah Ellis); Spirit of the Land (song lyrics, author unknown); Brian's Winter (a novel by Gary Paulsen), and A Rose is a rose is a rose (from the poem, "Sacred Emily" by Gertrude Stein). A short introduction will provide some background on each of the texts selected and also give details of the soundtracks that accompanied the visuals.

\section{The North Star}

The North Star (Reynolds, 2009) is a text that has grown into a website, a classroom guide, a musical, online activities/resources, and an online version of the story that is available without cost. On the website at www.peterhreynolds.com/ phr_thenorthstar.html Peter Reynolds explains, "The North Star is my tribute to "offthe-path" thinking - and to those who encourage it. Self-determination, creativity, hope, and vision are the cornerstones of this allegory." Jade's work provided a really interesting example of a multi-modal response from the perspective of a pre-service teacher. In her written rationale Jade wrote,

My multi-modal is split into two parts, my own response and my models for student responses. I did this to represent how teacher learning can shape student development. There are also various types of media included that I feel represent the necessity to appeal to various types of learners while selecting texts.

The themes in this text are universal and relevant to $\mathrm{J} / \mathrm{l}$ learners, and the theme of possibilities and dreams appealed to me as a future guidance counselor... The biggest message for me is that along any path one must stay true to oneself, help others along the way, and enjoy the walk. I look forward to taking the first steps down the trail of teaching and helping others take their first steps towards a lifetime of loving literature.

http://www.nipissingu.ca/faculty/susanej/videos/thenorthstar.mov

\section{Three Wishes: Palestinian and Israeli Children Speak}

Three Wishes is a small but powerful text that documents conversations between author Deborah Ellis and Palestinian and Israeli children when Ellis spent time in 2002 conducting interviews in both Israel and the Palestinian territories. In her Introduction, Ellis (2004) writes, 
The months preceding my visit had seen a number of suicide bombings by Palestinians, and the Israelis had responded by sending their army into Palestinian villages and refugee camps and placing virtually all Palestinians under house arrest or curfew... I asked the children I met to tell me about their lives, what made them happy, what made them afraid and angry, and how the war had affected them... (p. 8)

Jessica discussed the considerable impact this text had on her when she read it, and its relevance to her growth and development as a teacher. Her written rationale also clearly reflected her understanding of a broad definition of "literacy," and the need to welcome and acknowledge her students' interests in constructing and conveying meaning through a variety of modes. Jessica wrote,

I see a literate individual as someone who is able to derive and convey meaning from various sources while using their knowledge and experiences to make valuable connections. In my view, there can be no set definition of what constitutes literacy, as the definition itself is a dynamic one that is and always will continue to develop and evolve along with our society.... As $\mathrm{J} / \mathrm{l}$ educators, it is exceedingly important we not only provide our students with quality literature but also make ourselves aware of the many different approaches to instruction and learning that a selection of quality literature promotes...I want my students to absorb ideas, to question, and to make meaning, and to carry these skills and attitudes with them for the rest of their lives.... Three Wishes is comprised of Israeli and Palestinian children's stories, conceptions, and beliefs about the war they are living through every day. This book would not only educate my students on world issues but would also provide them with opportunities to make personal connections and provoke further questions....

http://www.nipissingu.ca/faculty/susanej/videos/threewishes.mov

\section{Spirit of the Land}

Ashley and Fay created a response to the song, Spirit of the Land (Unknown), explaining in their written rationale that quality literature in a $\mathrm{J} / \mathrm{I}$ classroom can be in the form of a novel, a textbook, song lyrics, fiction, non-fiction, poetry, magazines, speeches, read aloud, video, and more. They chose this text for their response, as, they explained, the song resonates with so many different aspects of Canadian life. Different individual responses stimulate different connections to the audio text of the lyrics images, thoughts, and feelings as represented visually here: http://www. nipissingu.ca/faculty/susanej/videos/spiritoftheland.mov 
In their written rationale, Ashley and Fay expressed how they might use their work as an exemplar for students at the grade six level and literacy across the curriculum (e.g., geography, history, art, language arts, music and drama):

Our literature response addresses the curriculum expectation 1.1-"identify a range of purposes for listening in a variety of situations, formal and informal, and set goals related to specific listening tasks (e.g,. describe stated and implied ideas in the lyrics of a song)." Students will read, listen to, and discuss the lyrics and then respond by creating their own multi-modal projects about what the song means to them and images the song conjures up for them...

\section{Brian's Winter}

The final example of a multi-modal literature response evokes sound and imagery based on the novel Brian's Winter (1996) by Gary Paulsen. Steve and Jessica responded via their personal interests in "the great outdoors" and utilized their own photographs and videography, along with narration, to construct their response to the text selected:

We chose Brian's Winter (the sequel to Hatchet), as it is appropriate to the present season. We listened to an audio version of the novel and used the print version for review.... Our response had to include something in the great outdoors.

After reading the novel, it makes one want to move into the wild and just observe! We chose to go winter camping and use digital photography to capture the sights. We took pictures of images we connected with in the story, such as beautiful winter scenes, animal tracks, and the campfire.... Our multi-modal response includes several forms of text: photography, video, and spoken word and these elements were pieced together into a mini movie. Our response also includes the physical act of getting outside and paying careful attention to the natural world, something we both hope to encourage our students to do....

http://www.nipissingu.ca/faculty/susanej/videos/brianswinter.mov

\section{A Rose is a rose is a rose... (Stein, 1913/1998, p. 387)}

Two teacher candidates, Andrew and Kendra, chose to work together on their multi-modal response and selected a line from a Gertrude Stein poem, "Sacred Emily," as their text. Their multi-modal response conveyed interpretations of the 
poem expressed through images of all kinds of roses and accompanied by a piano solo. They wrote:

We closely examined the poem entitled "Sacred Emily" and selected one sentence in particular that we would have students focus attention on. The sentence "Rose is a rose" was chosen because it was often interpreted, read and understood in many different ways depending on the audience. Gertrude initially meant for the first "Rose" to represent the name of a person. However, she later altered this version to include " $A$ " Rose is a rose et al. By adding just one letter the meaning of this sentence changed dramatically and was subsequently interpreted as "things are what they are" — a statement of law and identity....

... In order to portray the sentence, as it was known for its later meaning, we chose to show various types of roses via a movie montage created in iMovie and accompanied by Comptine d'un autre été l'après-midi, composed by Yann Tierson. Our interpretation enables viewers to see how a rose really is just a rose. However, a rose can be seen to symbolize different characters or personalities, it can be different colours, shapes, dead or alive, and in a multitude of locations around the planet. Ultimately, a rose is a flower that signifies love and relationships and different colours represent different variations of love and emotion...

\section{Discussion}

As previously noted, the creation of these multi-modal literature responses generated considerable interest and enthusiasm in classes, and pre-service teachers were rapidly engaged in thinking about how to approach and complete this work. $A$ great deal of learning about literature selections relevant to $\mathrm{J} / \mathrm{l}$ classrooms for language arts and many other areas of the curriculum was accomplished over time, as well as some impressive demonstrations of the effective integration of technology for teaching and learning. As the samples of work included illustrate, multi-modal responses were constructed using digital images, text, collage, art forms, music, movement, drama, narration, movie clips, and a wide range of software applications were incorporated into the process including Quick Time, Key Note, Pages, i-movie, i-tunes, and even the creation of related websites.

The extensive range of genres in the texts they selected represented picture story-books, poetry, art combined with poetry, novels, song lyrics, and samples of 
non-fiction (e.g., text books, articles, biography, anthologies of students' voices). The responses generated reflected thoughts, feelings, complex connections with the text, "big ideas," and themes inferred and interpreted from the various texts. The pre-service teachers commented over and again on how much the opportunity to create a multi-modal response "made sense" to them-and how much they looked forward to trying it out with school-age students in their own classrooms. The freedom from "lesson plans" and the opportunity to think creatively and "multi-modally" also appeared to be a further catalyst for original, highly thought-provoking "thinking like a teacher," and the critical responses that resulted.

Initial teacher education programs, while often criticized for being constrained in terms of time available, are best regarded as a beginning and not an end in themselves. Expert teachers are not the result of one-year teacher education programs. Calderhead and Shorrock (1997) describe the complexities involved in the ongoing nature of what I tend to refer to as the teacher education continuum, i.e., preservice teacher education and ongoing professional learning:

It is clear that learning to teach involves more than the mastery of a limited set of competencies. It is a complex process. It is also a lengthy process, extending, for most teachers, well after their initial training. The multidimensional nature of learning to teach has often not been fully recognized in the design of initial teacher education courses, which are often tightly constrained in terms of both time and human resources. (p. 194)

The experience of completing the multi-modal response assignment appeared to enable pre-service teachers to enact what Loughran (2006) refers to as "Articulating a knowledge of practice" (p. 66). As a teacher educator, I believe an important component of initial teacher education is the design and completion of thoughtful, rigorous, authentic, and meaningful assignments. Assigned work should require thoughtful application, and articulation of learning. By making the very best possible use of time available, initial teacher education programs must seek to offer candidates a range of authentic experiences that clearly demonstrate ways in which practice informs theory, theory informs practice, and the relevance of ongoing professional development.

The successful integration of technology in practice is a foundational component in all teacher education programs at Nipissing and the context of the iTeach program and its expectations for graduates, undoubtedly, was a significant enabler in the creation of these multi-modal responses to literature. As one teacher candidate commented: 
By having the emphasis on technology (in the iTeach program and in our courses generally), I feel I have a much better handle on linking technology with literacy, allowing me to better integrate multi-modal responses into my class lessons-and across the curriculum!

\section{Possibilities and Future Directions for Inquiry}

Dynamic whole class and small group discussions, as well as numerous conversations with individuals, were facilitated, enhanced and observed during this inquiry and the work completed by teacher candidates. Enthusiasm for, and engagement in, the task of responding to an authentic assignment (another "way in" perhaps for those who did not particularly relish teaching/learning about language arts?) were all clearly evident throughout the process-before, during, and after creation of the multi-modal responses. Once again, perhaps the voices of teacher candidates who contributed to this paper say it best themselves:

After the first reflection paper and class discussion I had decided for sure that language was not my thing... but after the break and into the "home stretch" $L A$ was beginning to win me over. The multi-modal assignment was something I really threw myself into... it not only got us to think about how we would teach critical literacy but it also gave us a chance to go through the process we'd ask our students to go through.

It used to be that the thought of teaching language arts terrified me! Writing, spelling have never been my strong suits... but I have come to see LA as truly "cross-curricular" and ... the multi-modal response allowed us the freedom to choose how to approach this assignment and produce work using skills we were strong in.

Throughout the year, this course presented some very interesting (and useful) assignments... The multi-modal response was truly the most unique since it fostered so many different ways of thinking and responding in one presentation. This is something I'll definitely use in future classrooms since it gets students to do much more than simply write to respond to literature.

Increasing awareness of developing and enacting a pedagogy of teacher education (Loughran, 2006; Russell \& Loughran, 2007) and ongoing study of my own 
efficacy as a teacher educator were central to this initial inquiry. The outcomes expanded my own "learning about teaching teachers" and, more specifically, a focus on multi-modal literature response as literacy teacher education. I have already noted some indicators for "fine-tuning" of the assignment itself, such as ensuring references and acknowledgements are included where appropriate in "credits" at the end of the responses. Some responses conveyed these very well, others not at all. Steve and Jessica's work on Brian's Winter demonstrates one of the best in terms of clearly acknowledging "credits" for (their own) photography as well as the book's title and date of publication, and audio-book recording. This is one I would share in future classes to draw attention to the need to credit images, audio clips, movie clips and so on as I found such sources were frequently not acknowledged in the multi-modal responses submitted. In the age of Internet research, I believe citations are as essential to work of this nature as they would be to, for example, more traditionally "written" responses, and must be included. Therefore, this is a teaching point that needs to be considerably emphasized next time, with the sharing of examples of work that include appropriate "credits" as exemplars.

Professional learning about integrating educational technology as part of my own classroom practice is constantly enriched as a direct result of the iTeach program. Ongoing learning and experiences include the many different programs, software, and the invaluable "mentoring" available that I, as a "digital immigrant" (Prensky, 2001) benefit from, as a result of working alongside my students most of whom would qualify as "digital natives." As an instructor, I continue to learn so much from my teacher candidates as a result of our work together-as digital natives and immigrants.

More research is needed and recommended in order to better understand ways to successfully bridge print and digital literacies in teacher education and school classrooms and to avoid perpetuating "traditional only" approaches to language and literacy. For example, pre-service teachers in this group also commented on 1) how interested their Associate Teachers had been in both viewing and (subsequently) experimenting with the multi-modal responses in their classrooms during final placement and 2) the benefits of the opportunity to share responses completed with colleagues in class. One pre-service teacher reflected as follows,

Sharing in class also gave me the opportunity to consider the wide variety of points of view of my colleagues. At no other time was it clearer to me that we all bring our own unique worldview to the same text, and thus interpret that text in very different ways. This kind of reflective practice, coupled with a collegial 
sharing of opinions, is exactly the type of atmosphere I want to build and support in my own classroom...

Whether an experienced teacher or one who is just graduating, we can capitalize on the many opportunities for "learning from each other" as we all continue to learn about teaching our "clientele" in schools who are "growing up digital" and creating digital futures (Tapscott, 1998, 2009). Continuous professional learning not only promotes growth and development in our own knowledge and practice as individuals, but also offers new ideas and opportunities for sharing that learning with the colleagues and students with whom we work. A genuine sense of confidence, trust, and support in collegial environments are critical contributing factors to success when trying anything new.

Teaching and learning through multi-modal literature response is but one way to approach the "bridging" of print and digital literacies. This innovative approach should not be regarded as a "replacement" for other interactive oral and written responses to literature, but rather as an extension of these as relevant to contemporary classrooms. However, based on my experience to date with the completion of this multi-modal assignment by teacher candidates, and my ongoing inquiry into the related processes, multi-modal literature responses provide powerful learning experiences. It is my hope that the five examples of responses and "students' voices" in this paper will provide starting points for explorations of multi-modal literature responses by others interested in literacy teacher education and the development of innovative assignments.

To conclude, as a researcher/practitioner, the exploratory inquiry reported here served to pique my own interest in the whole topic of multi-modal literature response and teacher education. Most recently, it has become evident that further investigation of technical details beyond the ability to merely craft a multi-modal response through images, text, music, movement, etcetera need further attention. Specifically, legalities related to potential copyright infringement continue to inform the work of the pre-service teachers and my own inquiry. As a result, the assignment is continually being improved and enhanced by the "fine-tuning" of expectations and advice given to those completing the multi-modal responses. (For example, something we will be discussing in classes next year is the selection of music already in the "public domain" and/or available through Creative Commons without disrupting the creative process. In this regard publishing and sharing complete examples in their entirety [i.e., including all "modes"] may be greatly facilitated). 
I plan to conduct further research in this area to acquire greater understanding and insights about the knowledge and experience gained by teacher candidates as a result of their participation in coursework of this nature. The kinds of questions to which I believe we need more answers include: 1) What important outcomes of pre-service literacy teacher education can be identified as a result of the kind of coursework described here? 2) What are the implications of experiential learning in this area for the developing practice of J/I teachers?; 3) What are some of the specific challenges and complexities involved in innovative work of this nature? and how do we effectively manage these complexities? and 4) What are some different ways to continue providing support for teachers who attempt to effectively "bridge" print and digital literacies in contemporary $\mathrm{J} / \mathrm{I}$ classrooms?

\section{References}

Anstey, M., \& Bull, G. (2006). Teaching and learning multiliteracies: Changing times, changing literacies. Newark, DE: International Reading Association.

Atwell, N. (Ed.). (1990). Coming to know: Writing to learn in the intermediate grades. Portsmouth, NH: Heinemann.

Calderhead, J., \& Shorrock, S. B. (1997). Understanding teacher education: Case studies in the professional development of beginning teachers. London: Falmer Press.

Ellis, D. (2004). Three wishes: Palestinian \& Israeli children speak. Toronto, ON: Groundwood Books.

Freebody, P., \& Luke, A. (2003). Literacy as engaging with new forms of life:The "four roles" model. In G. Bull \& M. Anstey (Eds.), The literacy lexicon. (2nd ed.). Frenchs Forest, NSW: Pearson Education Australia.

Kooy, M., \& Wells, J. (1996). Reading response logs: inviting students to explore novels, short stories, plays, poetry and more. Markham, ON: Pembroke Publishers.

Kress, G., \& van Leeuwen, T. (1996). Reading images: The grammar of visual design (2nd ed.). New York: Routledge.

Kress, G., \& van Leeuwen, T. (2001). Multimodal discourse: The modes and media of contem- porary communication. New York: Hodder Arnold.

Loughran, J. (2006). Developing a pedagogy of teacher education: Understanding teaching and learning about teaching. New York: Routledge.

Parsons, L. (1990). Response journals. Markham, ON: Pembroke Publishers.

Paulsen, G. (1996). Brian's winter. New York: Delacorte Press.

Prensky, M. (2001). Digital natives, digital immigrants. On the Horizon, 9(5), 1-6.

Reynolds, P. ( 2009). The North star. Somerville, MA: Candlewick Press.

Rosenblatt, L. (1978). The reader, the text, the poem: The transactional theory of the literary work. Carbondale and Edwardsville: Southern Illinois University Press.

Rosenblatt, L. (1994). The transactional theory of reading and writing. In R. B. Ruddell, M. R. Ruddell \& H. Singer (Eds.), Theoretical models and processes of reading (4th ed., pp. 1057-1092). Newark, DE: International Reading Association.

Rosenblatt, L. (2005). Making meaning with texts: Selected essays. Portsmouth, NH: Heinemann. 
Russell, T., \& Loughran, J. (Eds.). (2007). Enacting a pedagogy of teacher education: Values, relationships and practices. New York: Routledge.

Smith, K. (2008). Louise Rosenblatt: An enduring legacy in the teaching of literature. English Quarterly, 38(2-3).

Stein, G. (1913/1998). Gertrude Stein: Writings, 1903 to 1932, vol. 1. The Library of America.
Tapscott, D. (1998). Growing up digital: The rise of the net generation. New York: McGraw Hill.

Tapscott, D. (2009). Grown up digital: How the net generation is changing your world. New York: McGraw Hill.

Unknown. Spirit of the Land. (Words and Music).

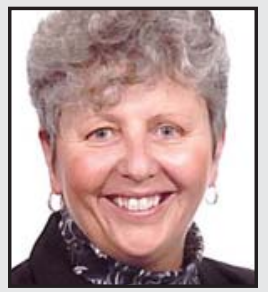

Susan E. Elliott-Johns is currently a tenured Assistant Professor at Nipissing University where she teaches courses in both the pre-service and graduate programs in Language Arts and Literacy. Prior to joining the faculty at Nipissing, Susan enjoyed a long and successful career in public education as a teacher (K-8), literacy consultant, teacher educator, and elementary school administrator. She has provided leadership in numerous workshops, conference presentations, additional qualifications courses, and publications for teachers, administrators, and other teacher educators in Canada, Europe, the United States and Australia.

LINK TO:

www.nipissingu.ca/faculty/susanej 